\title{
PEMBERDAYAAN MASYARAKAT DENGAN USAHA KULINER MELALUI DIVERSIVIKASI PRODUK OLAHAN IKAN PATIN DI KAMPUNG PATIN DESA KOTOMESJID KECAMATAN XIII KOTO KAMPAR PROVINSI RIAU
}

\author{
Delfi Yanti ${ }^{1}$, Eni Sumiarsih ${ }^{2}$, Maryantina ${ }^{3}$ \\ ${ }^{1)}$ Sekolah Tinggi Pariwisata Riau Pekanbaru \\ e-mail: delfiyanti.stpriau@gmail.com
}

\begin{abstract}
Abstrak
Berdasarkan hasil dan pengamatan penelitian ini bertujuan untuk memberikan pengertian dan pengetahuan kepada masyarakat akan pentingnya pengelolaan Ikan Patin untuk menopang kehidupan., dan memberikan informasi tentang manfaat dan penyebab kerusakan ekosistem Iakan Patin, serta memberikan dan meningkatkan pengetahuan dan tindakan masyarakat, khususnya masyarakat tentang cara pengelolaan ikan patin berbasis masyarakat. Metode yang dilakukan yaitu dengan cara penyadaran untuk meningkatkan pengetahuan tentang usaha kuliner dengan produk olahan ikan patin. Kemudian pemberikan penyuluhan dan mempraktekan langsung produk olahan ikan patin sebagai usaha kuliner kepada masyarakat kampung patin desa koto Kampar kecamatan XIII Koto Kampar Riau kegiatan Hasil dari Pengabdian Masyarakat ini berjalan dengan lancar dan sesuai rencana yang sudah disusun. Masyarakat kampung patin desa koto mesjid kecamatan XIII Koto Kampar sangat bersemangat dan aktif dalam mengikuti Program Pengabdian Masyarakat yang berupa penyuluhan dan praktek. Kemudian diberikan juga inovasi untuk membuat produk olahan ikan patin dengan bentuk dan rasa yang berbeda dengan mempraktekkan secara langsung. Sehingga ikan patin yang relatif murah bisa menjadi produk yang berbeda dan memiliki nilai lebih dan bernilai jual lebih tinggi. Dari kegiatan ini peserta pelaku/ masyarakat mampu untuk membuat produk olahan dari ikan patin yang berkualitas dan mampu melakukan inovasi baru terhadap ikan patin dengan menghasilkan variasi baru.
\end{abstract}

Kata kunci: Produk Olahan Ikan Patin

\begin{abstract}
Based on the results and observations of this study aims to provide understanding and knowledge to the community on the importance of managing catfish to sustain life, and provide information about the benefits and causes of damage to the Patin fish ecosystem, as well as providing and increasing knowledge and actions of the community, especially the community on how to manage community-based catfish. The method used is by way of awareness to increase knowledge about the culinary business with processed catfish products. Then giving counseling and directly practicing processed catfish products as a culinary business to the patong village community Kampong Koto Kampar XIII sub-district Koto Kampar Riau The results of Community Service activities run smoothly and according to the plans that have been prepared. The patin village community, Koto mosque, XIII sub-district, Koto Kampar, are very enthusiastic and active in participating in the Community Service Program in the form of counseling and practice. Then given an innovation to make processed catfish products with different shapes and flavors by practicing directly. So that relatively cheap catfish can be different products and have more value and higher selling value. From this activity participants participants / communities are able to make processed products from quality catfish and are able to innovate new catfish by producing new variations.
\end{abstract}

Keywords: Processed catfish products 


\section{PENDAHULUAN}

Kampar merupakan salah satu kabupaten yang terdapat di Provinsi Riau yang memiliki keindahan alam yang dijadikan destinasi pariwisata, yang cukup terkenal didaerah ini adalah keindahan Waduk PLTA Koto Panjang dan Candi Muara Takus, Puncak Kompe, Danau Rusa, Air Terjun Gulamo dan lain-lain yang saat ini diminati pengunjung, baik domestic, maupun manca Negara. Tidak hanya keindahan dan pesona alam yang eksotik yang terdapat di Kampung Patin Koto Mesjid, tetapi daerah ini juga memiliki potensi Desa Wisata yang perlu dikembangkan menjadi Desa wisata yang maju.

Desa Koto Mesjid merupakan Desa yang ada di Kabupaten Kampar Kecamatan XIII Koto Kampar, desa ini dikenal dengan "Kampung Patin". Karena di desa ini terdapat kolam budidaya yang membudidayakan khusus ikan patin. Usaha ikan patin di Desa Koto Mesjid ini dimulai pada tahu 2003-2012 dengan bantuan PT. Telkom Pekanbaru. Kondisi lingkungan Desa Koto Mesjid merupakan wilayah yang berada di pingiran Waduk PLTA Koto Panjang. Hal ini menjadikan Desa Koto Mesjid, selain sebagai pusat pengembangan perikanan kolam darat, juga berpotensi dalam pengembangan Keramba Jaring Apung (KJA) di waduk PLTA Koto Panjang. Perkembangan dibidang perikanan Desa Koto Mesjid juga tidak terlepas dari dukungan sumber air yang sangat memadai. Pada awalnya Koto Mesjid tidak memiliki sumber air dan tergolong daerah yang kurang baik untuk budidaya ikan. Namun, sejak ditemukannya sumber mata air berupa air bawah tanah yang sangat melimpah, Desa Koto Masjid berubah menjadi salah satu kawasan budidaya air tawar yang cukup dikenal dengan pemanfaatan air melalui sumur bor.

Produk perikanan diharuskan memenuhi persyaratan yang cukup ketat, dalam hal kualitas, keamanan pangan dan ketertelusurannya (traceability). Salah satu pasar yang paling ketat persyaratannya yang menekankan bahwa keamanan pangan harus terjamin sejak produksi sampai ke meja makan dan dapat ditelusuri riwayatnya. Oleh karena itu, di kampong patin desa koto masjid kecamatan XIII Koto Kampar ini telah mengembangkan budidaya ikan patin berdasarkan permintaan pasar, sehingga ikan patin tidak mengalami kesulitan untuk menembus pasar khusus nya sekecamatan yang ada di propinsi Riau hingga menembus pasar Kuala Lumpur dan Singapura. Ikan patin menjadi sangat populer karena budidayanya mudah, pertumbuhannya cepat, dan mudah beradaptasi dengan berbagai lingkungan. Di samping itu, teknologi budidaya ikan patin sudah berkembang dan dapat dilakukan dengan berbagai sistem yaitu dengan karamba di sungai-sungai, waduk, kolam. Ikan patin merupakan komoditas hasil budidaya perikanan yang pasarnya cukup menjanjikan. Dalam kurun waktu dua tahun terakhir ini, permintaan ikan patin meningkat dua kali lipat. Potensi pasar tersebut perlu dimanfaatkan dengan lebih menggalakkan budidaya ikan patin di Indonesia yang potensi lahannya cukup luas. Pasar ikan patin selama ini masih dikuasai Vietnam dengan ekspor dalam bentuk fillet dan produk olahan berbasis surimi. Selain dipasarkan dalam bentuk fillet, ikan patin sangat cocok untuk diolah menjadi berbagai macam produk berbasis surimi yang trend pasarnya semakin meningkat. Ikan patin dapat diolah secara tradisional maupun modern sehingga dapat meningkatkan nilai tambah ikan patin secara berarti. Akan tetapi dalam era globalisasi ini, pemasaran produk ikan hasil budidaya ke berbagai negara menghadapi banyak hambatan.

Tantangan yang harus dihadapi di pasar internasional adalah produk perikanan diharuskan memenuhi persyaratan yang cukup ketat dalam hal kualitas, keamanan pangan, dan ketertelusurannya (traceability). Dalam industri pengolahan ikan patin akan dihasilkan limbah yang cukup banyak yaitu sekitar $67 \%$ dari total ikan patin. Limbah tersebut dapat diolah dan dimanfaatkan menjadi gelatin, konsentrat protein, tepung ikan, silase, atau minyak biodiesel sehingga dapat memberikan nilai tambah dalam industri ikan patin. Agar industri ikan patin dapat berkembang di Indonesia maka diperlukan dukungan dari pemerintah, lembaga riset, dan swasta untuk mengembangkan sentra budidaya ikan patin di suatu lokasi.

Ikan patin atau yang dalam dunia perdagangan dikenal dengan catfish merupakan komoditas baru dalam dunia perikanan. Ikan ini baru dipasarkan sebagai komoditas hasil budidaya perikanan selama satu dasawarsa terakhir ini. Sebelumnya masyarakat penggemar seaf ood jarang mengenal nya dibandingkan dengan udang, ikan tuna, dan salmon. Namun sekarang ikan patin menjadi komoditas yang sangat penting dan popular karena pasarnya berkembang dengan pesat. Salah satu negara yang berhasil mengembangkan budidaya ikan patin dan merajai pasar adalah 
Vietnam. Produksi budidaya ikan patin di kampung patin desa Koto Masjid Kecamatan XIII Koto Kampar ini sangat berpotensi sekali sehingga dapat menghasilkan produk unggulan dan dapat meningkatkan nilai jual dari ikan patin itu sendiri. Pemberdayaan masyarakat akan dilakukan pada masyarakat, Kampung patin desa Koto Mesjid Kecamatan XIII Koto Kampar Riau. Pemanfaatan sumberdaya dan pemanfaatan hasil tambak/ kolam ikan patin yang belum maksimal sehingga tidak dapat diolah sebagaimana baiknya dan akhirnya terbuang hasil perikanannya.

Upaya yang dilakukan untuk pemanfaatan hasil tambak / kolam ikan patin secara optimal dan berkelanjutan adalah dengan melibatkan masyarakat didalam pengelolaan ini, Umumnya masyarakat desa Koto Masjid masih dikategorikan sebagai masyarakat prasejahtera. Masih sangat minimnya pengetahuan masyarakat akan arti penting pengolahan produk turunan dari ikan patin bagi kehidupan mereka. Padahal ikan patin dapat dimanfaatkan sebagai sumberdaya masyarakat. Sehingga perlu upaya untuk meningkatkan income masyarakat dan juga meningkatkan pendapatan asli daerah. Permasalahan lingkungan yang ditemukan dalam kaitan dengan mengembangkan Usaha kuliner ikan patin menjadi daya tarik masyarakat untuk mengolah berbagai kuliner turunan dari ikan patin. Upaya meningkatkan nilai jual ikan patin. Identifikasi potensi ikan patin sebagai daya tarik ekowisata. Mengenal konsep dan pelaksanaan sertifikasi pariwisata berwawasan ;lingkungan dan berkelanjutan dibidan kuliner. Mengkaji pengolahan sampah di bidang pariwisata (persentase landfilled, efektivitas, jenis-jenis sampah, dll).

\section{METODE}

Kegiatan Pemberdayaan dan penyuluhan ini dilakukan kepada masyarakat kampong patin Desa Koto Masjid Kecamatan XIII Koto Kampar Riau. Metode yang akan dilaksanakan untuk mencapai tujuan adalah : Penyadaran untuk meningkatkan pengetahuan tentang usaha kuliner dengan produk olahan ikan patin. Memberikan penyuluhan langsung tentang produk olahan ikan patin sebagai usaha kuliner kepada masyarakat kampong patin desa koto Kampar kecamatan XIII Kotoi Kampar Riau Kemudian mempraktekan langsung produk unggulan ikan patin seperti fish cake, jelly fish, udang tiruan, crab tiruan, bakso, nugget, Fish Burger Patin, Siomay Ikan Patin, Mpek-mpek Patin, Patin Asam Manis, Ikan Dori, Tek-wan Ikan Patin, Otak-otak Ikan Patin, Sate Ikan Patin dan lain-lain.

\section{Jadwal Kegiatan}

\begin{tabular}{|c|c|c|c|c|c|c|c|}
\hline \multirow{2}{*}{ No. } & \multirow{2}{*}{ Jenis Kegiatan } & \multicolumn{6}{|c|}{ Waktu (bulan ke.....) } \\
\hline & & 1 & 2 & 3 & 4 & 5 & 6 \\
\hline 1. & $\begin{array}{l}\text { Persiapan: } \\
\text { Perizinan, pelatihan, pembagian kerja dan sosialisasi }\end{array}$ & & & & & & \\
\hline 2. & Pelaksanaan pelatihan & & & & & & \\
\hline 3. & Evaluasi & & & & & & \\
\hline 4. & Diskusi Tim & & & & & & \\
\hline 5. & Penyusunan laporan & & & & & & \\
\hline 6. & Penyerahan laporan & & & & & & \\
\hline
\end{tabular}

\section{HASIL DAN PEMBAHASAN}

Setelah melalui serangkaian kegiatan penyuluhan dan praktek, dapat dikatakan bahwa kegiatan Program Pengabdian Masyarakat ini berjalan dengan lancar dan sesuai rencana yang sudah disusun. Masyarakat kampung patin desa koto mesjid kecamatan XIII Koto Kampar sangat bersemangat dan aktif dalam mengikuti Program Pengabdian Masyarakat yang berupa penyuluhan dan praktek. Peserta diberikan pengarahan tentang cara untuk menghasilkan produk ikan patin yang berkualitas. Seperti pengplahan produk turunan ikan patin Fish barger, Mpekmpek ikan patin, siomay ikan patin, asam manis ikan patin, ikan dori, tek-wan, otak-otak ikan patin, sate ikan patin, begitu juga dengan warna untuk setiap masakan yang bervariasi . Selain 
itujuga pengelompokan rasa yang juga bervariasi dalam setiap masakan . Kemudian diberikan juga inovasi untuk membuat produk olahan ikan patin dengan bentuk dan rasa yang berbeda dengan mempraktekkan secara langsung. Sehingga ikan patin yang relatif murah bisa menjadi produk yang berbeda dan memiliki nilai lebih dan bernilai jual lebih tinggi. Dari hasil tersebut dapat dilihat bahwa setiap peserta / masyarakat sudah memahami cara untuk menghasilkan produk olahan patin yang berkualitas dan inovasi yang bisa dilakukan bagi masyarakat dan pelaku usaha kuliner produk olahan ikan patin yang memiki bentuk dan warna yang kurang bagus, sehingga terbentuk variasi baru dari produk olahan ikan patin.

Berdasarkan hasil kegiatan Program Pemberdayaan yang berbentuk penyuluhan dan praktek secara langsung, dapat dikatakan bahwa kegiatan ini berhasil dilakukan. Hal ini sesuai dengan target yang telah ditentukan sebelumnya. Solusi Pengembangan Pemberdayaan (Pelatihan) adalah: pertama, Pengorganisasian yang baik, Pengorganisasian yang terencana dengan baik sesame tim Pelatihan yang dapat menolong dalam menyelesaikan pelatihan sehingga bisa memantau kegiatana atau tahapan yang sudah selesai dilakukan. Kedua, Berpikir kreatif Kreativitas yang dilakukan dalam pemberdayaan sangat dibutuhkan dalam pelatihan ini. Berpikir kreatif dengan bersedia menampung ide-ide baru, terus menambah wawasan dapat di gunakan untuk mengembangkan pelatihan. Ketiga, Mencatat berbagai hal secara menyeluruh Data yang menyeluruh yang digunakan dalam pelatihan ini untuk mengamati perkembangan pengetahuan peserta pelatihan, mengetahui adanya kekurangan dalam sebuah proses, atau mengambil langkah strategi baru. Keempat, Konsisten, Saat melakukan pelatihan ini konsisten dalam berperilaku baik akan membentuk kebiasaan yang positif. Selain itu juga dapat menginspirasi para peserta pelatihan melakukan hal yang sama. Kelima, Pahami risiko Membuat penghitungan risiko yang tepat dapat meminimalkan hal-hal yang tidak diinginkan terjadi dalam pelatihan, dengan memahami risiko yang mungkin terjadi. Keenam, Tetap fokus pada tujuan yaitu mengadakan pelatihan kepada masyarakat kampung patin Kampar. Ketujuh, Pelayanan yang baik, Pelayanan kepada peserta pelatihan menerima keluhan memberikan solusi dan dapat mengedukasi peserta pelatihan dengan baik.

\section{SIMPULAN}

Dari hasil dan pembahasan pada BAB sebelumnya dapat dikatakan bahwa peserta pelaku/ masyarakat mampu untuk membuat produk olahan dari ikan patin yang berkualitas dan mampu melakukan inovasi baru terhadap ikan patin dengan menghasilkan variasi baru. Saran untuk Program Pendampingan pengabdian Masyarakat ini, berupa:

Kegiatan Program Pendampingan Pengabdian Masyarakat ini yang berupa pembekalan mengenai peningkatan produk olahan ikan patin yang berkualitas. Para peserta/ masyarakat dan pelaku usaha kuliner sebaiknya lebih memperhatikan kualitas ikan patin dari segi Bentuk yang meliputi Ukuran, Ketebalan dan rasa yang sama untuk setiap kegiatan produksi. Meningkatkan Kualitas Produk ikan patin dari segi Rasa (Asam dan Manis, gurih, pedas) yang merata untuk setiap kegiatan produksi. Masyarakat dan Para pelaku usaha ikan patin sebaiknya menggunakan / memperhatikan tingkat kualitas ikan patin yang digunakan untuk berbagai jenis masakan ikan patin dan juga sebaikya masyarakat dan pelaku usaha melakukan pengelompokkan rasa untuk ikan patin yang dihasilkan.

Kegiatan Program pendampingan pengabdian Masyarakat ini juga disertai dengan praktek langsung tentang inovasi yang bisa dilakukan terhadap ikan patin. Dengan melakukan inovasi terhadap ikan patin dapat menambah nilai jual dan menciptakan variasi baru ikan patin, yang bisa menambah konsumen dan pelanggan.Sehingga pelaku usaha mau mencoba dan memproduksi ikan patin dengan variasi baru. Tim berharap Program Pendampingan Pengabdian Masyarakat bagi masyarakat dan pelaku usaha kuliner dapat berkelanjutan, karena masih banyak usaha yang harus dilakukan dan diterapkan oleh pelaku usaha produk ikan patin untuk menghasilkan produk yang berkualitas dan bisa bersaing dengan produk sejenisnya.

Pemberdayaan Masyarakat Dengan Usaha Kuliner di kampung patin desa Koto Mesjid Kecamatan XIII Koto Kampar Riau bertujuan Memberikan pengertian dan pengetahuan kepada masyarakat akan pentingnya pengelolaan Ikan Patin untuk menopang kehidupan, memberikan informasi tentang manfaat dan penyebab kerusakan ekosistem Iakan Patin, memberikan dan 
meningkatkan pengetahuan dan tindakan masyarakat, khususnya masyarakat tentang cara pengelolaan ikan patin berbasis masyarakat. Dan dapat menyadarkan para peserta yang semula belum tahu akan pentingnya pemanfaatan dan pengelolaan ikan patin, serta dapat menggugah dan menimbulkan keinginan masyarakat yang tidak ikut kegiatan penyuluhan untuk berbuat dan bersikap seperti peserta yang telah ikut penyuluhan. dapat menambah partisipasi masyarakat dalam kelompok-kelompok pengelolaan ikan patin berbasis masyarakat, terutama di Kampung patin Desa Koto Mesjid Kecamatan XIII Koto Kampar Riau.

\section{DAFTAR PUSTAKA}

Butarbutar R, Soemarno. 2013. Environmental Effects of Ecotourism in Indonesia. Journal of Indonesian Tourism and Development Studies. E-ISSN: 2338-1647. Hlm 97-107.

Gaol HL. 2008. Kajian potensi daya tarik wisata Gua Terawang dan Loko Wisata Hutan Jati, Cepu Kabupaten Blora dan kemungkinan pengembangannya. Jurnal Kepariwisataan Indonesia 3(3):413-426.

Jovicic D, Dragin A. 2008. The Assessement of Carrying Capacity-A Crucial Tool for Managing Tourism Effects in Tourist Destinaation. Turizam. Vol 12. Hlm 4-11.

Lagmoj AM, Shokry KA, Hashemi AS, Zadegan KH. 2013. Defining the Ecotourism Carrying Capacity of Langeroud City (Case Study: Khorma Forest). Greener Journal of Social Sciences. Vol. 3 (9), Hal 447-457.

Ngabito M, Tuwo A, Achmad A. 2012. Kesesuaian dan Daya Dukung Ekowisata Pulau Saronde Kabupaten Gorontalo Utara Provinsi Gorontalo. [Jurnal]. Gorontalo (ID): Universitas Hasanuddin.

Risnayanti, Febrisa. 2015.Strategi Promosi Penyelengaraam Wisata Outbound Dalam Meningkatkan Kunjungan di Taman Agro Wisata Bukit Naang Kabupaten Kampar. Jurnal Ilmu Manajemen (Daya Saing). Vol 1 (188-194).

Rosalino, Luis M and Grilo, Clara. 2011. What drives visitors to Protected Areas in Portugal : accessibilities, human pressure or natural resources? Journal of Tourism and Sustainability 1 (1) : 3-11.

Sabri A, Marlina L. 2015. Potensi Prosesi Balimau Kasai Sebagai Atraksi Wisata Budaya Dalam Melestarikan Adat dan Budaya di Desa Batu Belah Kecamatan Kampar Kabupaten Kampar. Jurnal Ilmu Manajemen (Daya Saing). Vol 1 (136-145).

Siburian R. 2006. Pengelolaan Taman Nasional Gunung Leuser bagian Bukit Lawang Berbasis Ekowisata. Jurnal Masyarakat dan Budaya, Vol. VIII No.I/2006. Hal 67-90. Jakarta.

Sukma D, Basuni S, Sunarminto T. 2016. Pengembangan Manajemen Kawasan Ekowisata Budaya Candi Muara Takus Kampar Riau. Jurnal Media Konservasi. Vol 21 (159-167).

Syaiful, Syech, A. 2015.Upaya Dinas Kebudayaan dan Pariwisata Mempromosikan Mesjid Raya Pulau Penyengat Sebagai Daerah Tujuan Wisata di Tanjung Pinang Kepulauan Riau. Jurnal Ilmu Manajemen (Daya Saing). Vol 1 (154-162).

Trisoko G.R, Putra P.P. 2015. Strategi Pengelolaan Danau Kawah Putih Sebagai Objek Wisata di Kawasan Ciwidey Oleh PT. Perhutani (Persero) Unit III Bandung. Jurnal Ilmu Manajemen (Daya Saing). Vol 1 (118-126). 